\title{
Corporate Global Responsibility and Reputation Risk Management
}

\author{
Raffaella Cassano*
}

\begin{abstract}
The increasing attention placed by corporations on sustainable development due to the growing importance attributed to this issue by institutions at an international level, leads to a reconsideration of the concept of the global responsibility of companies as a pre-requisite for effective multi-stakeholder relationships.

All levels of responsibility are taken into consideration within this broad spectrum: legal, social, economic and environmental, leading to a more integrated approach to management of reputation risk. This study is a theoretical reflection on the relationship between the interests of stakeholders, the extent of corporate responsibility and management of reputation risk.
\end{abstract}

Keywords: Corporate Responsibility; Corporate Reputation; Stakeholder View; Reputation Risk; Risk Management; Multi-Stakeholder; Global Markets

\section{Corporate Responsibility and the Multi-Stakeholder Approach}

Great strategic and administrative complexity within companies results in a proportionate corporate global risk which draws the attention of financial and management scholars to the establishment of the concept of global responsibility which creates an effective relationship, based on trust and consent, between the various categories of stakeholders.

Markets are becoming more dynamic and therefore vulnerable with respect to their development and difficult to manage (Brondoni 2014). Social, cultural, political and economic expectations are increasing, and their intensity and importance is calling for more complex contents and structures. Opportunities for corporations in their search to create value require strategy focused on meeting the numerous objectives and the relative corporate risks (Salvioni 2003; Jamali 2008; Brown \& Forster 2013; Freeman 2017).

In this respect, it is necessary to effectively combine requirements of flexibility, cost effectiveness and results, establishing a broader corporate responsibility and meeting the different expectation of the stakeholders.

The beginning of the century witnessed one of the biggest corporate crises at a global level, often determined by a deficiency in governance and the control and risk strategy.

In the last few years, this situation led to a deep analysis of the processes, the structures and the functions of corporate governance even at a regulatory and

* Researcher of Business Administration, University of Brescia (raffaella.cassano@unibs.it)

Edited by: Niccolò Cusano University

ISSN: 1593-0319

Cassano, R. (2019). Corporate Global Responsibility and Reputation Risk Management, Symphonya. Emerging Issues in Management (symphonya.unicusano.it), 1, 129-142. 
institutional level. In this light, attention was placed by corporate financial analysts on matters relating to the corporate governance, risk management, control systems and good governance practices to be followed in order to satisfy the various expectation of the stakeholders and to maintain a management balance based on global corporate responsibility. (Donaldson \& Preston 1995; Freeman et al., 2010; Salvioni et al 2018).

The context in which companies operate is strongly affected by social environment and political shifts, such as:

- the elimination of spatial and temporal confines as a result of technological developments and the effects of market globalisation;

- the higher number of markets which offer more supply than demand;

- the consequent change in strategy adopted and management of corporations;

- the need to focus on consensus and trust in achieving corporate objectives.

Obviously, these events have had a significant impact on corporate governance both with respect to governance procedures and structures as well as with respect to control and risk management systems.

The company, being an open and dynamic system, operates on the basis of effectiveness and efficiency with management aiming for profitability while in line with principles of social awareness (Gandini et al., 2014). In fact, pursuit of financial balance is possible when the stakeholders objectives are adequately met. It is therefore safe to state that the principles of effectiveness, efficiency and sociality are strictly related. In other words, the durability and the financial autonomy of a company, therefore its economic viability, are strongly influenced first of all by its compliance with rules as well as reconciling the social and environment aspects while seeking the best possible financial results.

$\square$ Over time, this synergy has become a strategic path based on the belief that the ever-deeper integration between economic growth, social inclusion and environmental protection is a paradigm capable of creating shared value as well as to safeguard the world in which we live (Alberto Lavazza, Chairman of the Lavazza Group).

In other words, a new approach to the companies' role in society is emerging. (Salvioni \& Astori 2013).

In particular, this was due to the most recent fraud or company mismanagement, the emergence of new paradigms of sustainable development and models of stakeholder relations management.

However, it should be pointed out that the focus on corporate sustainability does not imply lesser importance of value creation and return on capital.

On the contrary, as already mentioned, in order to increase consent and resources becomes relevant: the interdependence between the management of relations with the environment, the capability to establish stakeholder engagement activities, the combination of economic, social and environmental responsibility and the definition of strategies and objectives in line with stakeholders expectations (Figure 1). 
Figure 1: Corporate Governance and Strategic Approach

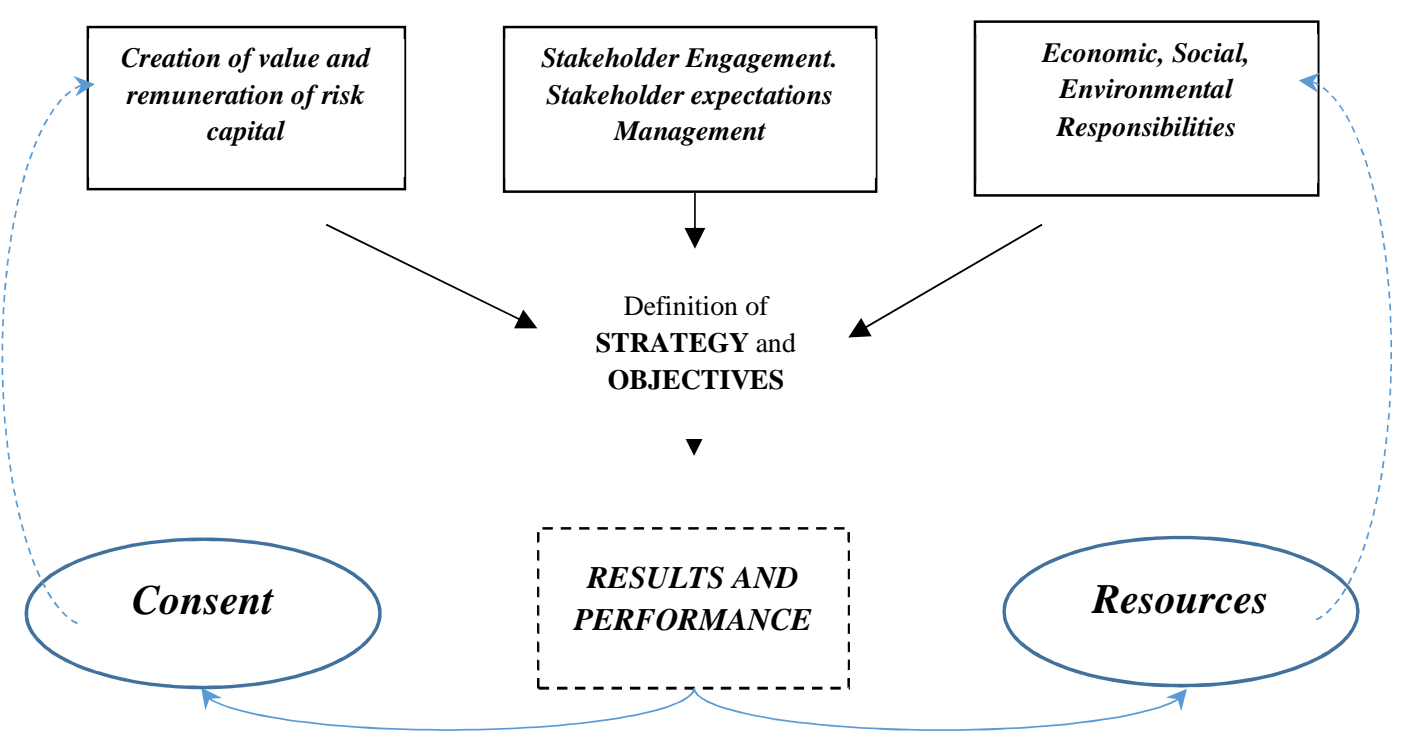

Establishing a wider concept of responsibility implies a deep rooted inspiration of the corporate culture which must steer the corporate structure and management towards equity values, responsible decision making, transparency and legality.

This is the only way that corporate conduct could be considered to be socially responsible or inspired by a broad concept of social awareness.

Therefore, for a more effective approach to corporate governance, careful consideration must be given to the expectations of stakeholders in view of a unified responsibility, even if expressed at different levels, together with the relative potential risks.

More specifically, recent developments in economic systems have highlighted critical issues that must be improved with respect to the environment, the stakeholder and companies.

This refers to the need of open governance, in line with a multi-dimension vision and a balanced application of the legal, financial and social aspects (Brondoni \& Bosetti 2018).

Moreover, the opportunity to adapt management systems to ensure coherence between governance decisions, administrative actions and satisfactory results is perfectly in line with the corporate risks system.

We can therefore state: the company's responsibility cannot arise separately, but as a result of an effective combination of the separate dimensions identified (legal, social, environmental and economic) according to a unified and global corporate vision (Porter \& Kramer 2006; Perrini \& Vurro 2013, Cassano 2013, Salvioni \& Gennari 2017). Therefore, the company's responsibility cannot be split up into separate dimensions, each detached from the other, but must be understood as the joint and unified participation in the long-term growth of the company (Figure 2). 
Figure 2: Corporate Responsibility and Multi-Dimensionality

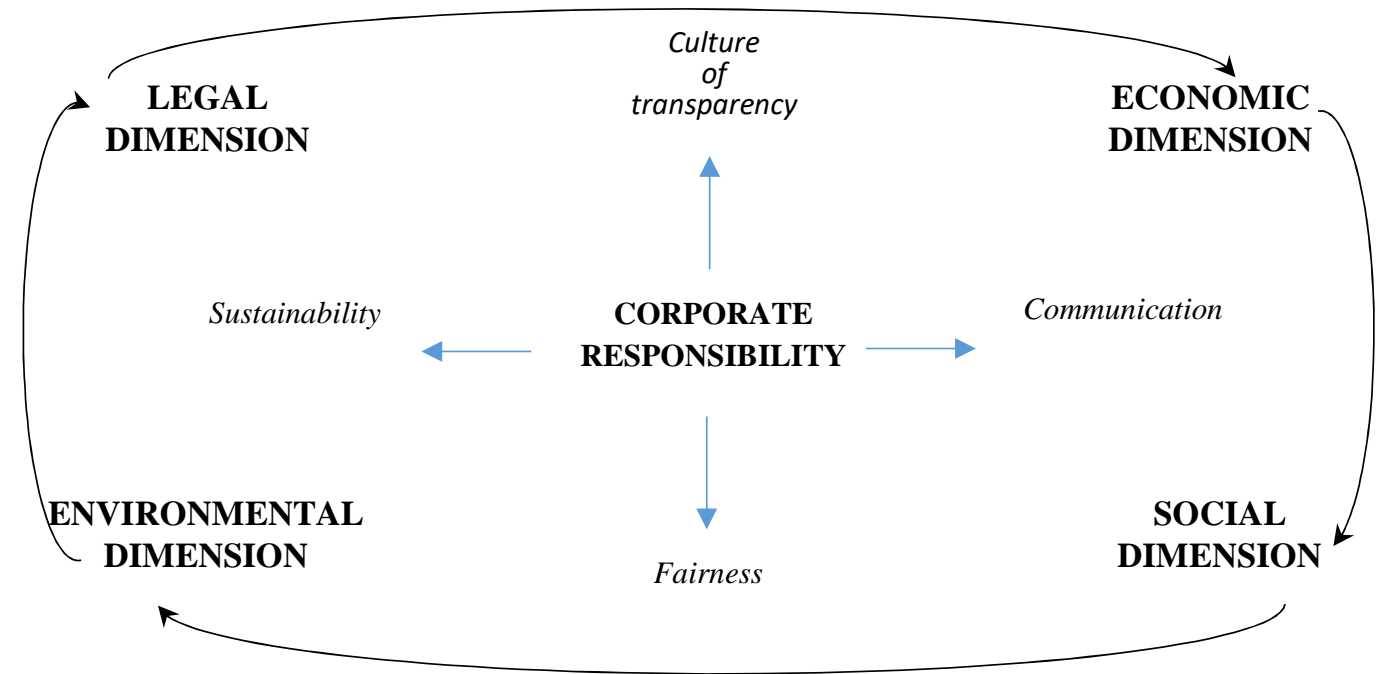

Although it is not possible to fix an order of preference of responsibility levels it must be pointed out that the legal aspect represents the essential element for all the dimensions identified. In this respect, while legal actions cannot be justified or allowed, operating conduct - linked to management strategic decisions - represents a natural course of corporate activities, strictly linked to subjective evaluations, the corporate culture and the risk awareness within each organisation.

Therefore, legal responsibility is of the essence and mandatory for the proper implementation of corporate responsibility.

The responsibility dimensions influence strategic decision making procedures, since they are at core of corporate conduct and consequently corporate activity. Actions undertaken by the company have a direct and/or indirect impact on results, enhance or restrict the company's performance which is in turn influenced by the external social environmental context and the particular phase in the company's life.

The cyclical system described constitutes the foundation of a strong corporate culture structure which manifests itself in the company's activities reflecting proper conduct and transparency as well as the effective will to share and participate in a corporate environment which is shared and partaken by everybody and geared to create long term value for the company (Salvioni et al., 2014).

In this case the internal control and risk management system plays a pivotal role and together with decision-making, actions and instruments intended to monitor, map out, anticipate and effectively manage present and potential corporate risks in a strategic manner.

Monitoring the consequences of these risks becomes strategic. In this respect, corporate governance extends its objects including the interests of all its internal and external network in line with an approach based on best practices and on exchange of information (Borgonovi 2007; Zucchella 2007; Brondoni 2010). 


\section{Managing Stakeholder Relations and Reputation}

What has been stated above shows the importance of relations between the company and interested parties as an expression of its ability to interpret the various exigencies, to gain the trust of its stakeholders and to manage the company's strategy long term strategy (Lowensberg 2009).

In a nutshell, "corporate reputation".

Corporate reputation is the overall judgment of the company by its stakeholders, built strategically for a long period of time as the approach adopted by the company when faced with the various circumstances and as a reaction to the various changes in surrounding events (Barnett et al., 2006). Corporate reputation is built over many years and remains relatively stable. It is crucial to the company's success and the result of random change, that is the multi-dimensional complexity of factors that make it unique to third parties, giving the company the possibility to obtain and maintain a competitive advantage.

According to Charles J. Fombrun, corporate reputation is "a collective representation... It gauges a firm's relative standing both internally with employees and externally with its stakeholders... A representation of perceptions of the company's past actions and future perspectives that describe the overall feelings of a company for its stakeholders from the comparison with its main rivals".

Fombrun defines companies' reputation as a strategic asset at risk in dealing with stakeholders. Other authors consider reputation as a critical intangible asset that create value for the company (Roberts \& Dowling, 2002). The definition of reputation considers, therefore, the collection of stakeholder knowledge regarding the same company (Rindova \& Petkova, 2005).

In the light of the above, reputation is influenced by the quality of the relationships that the company establishes with its stakeholders, and this is consequently reflected in the value that it creates or maintains for the company over time.

The quality of a company's reputation is essential to long term success. In this respect, a good reputation increases the trust placed by investors, employees, clients, management and audit entities in the company leading to better resources and potential for success (Doorley \& Garcia 2011; Perrini \& Vurro 2013).

Acquiring a good reputation is therefore the result of responsible decision- making and actions which can be gauged and based on maintaining a constant balance between the different expectations of the various shareholders (Fombrun et al., 2015).

The adoption of CSR-oriented business strategies can therefore reduce the risk of an environmental or social crisis, or at least contain the harmful effects of such a situation. Moreover, CSR actions can potentially generate goodwill and a better internal climate, or "moral capital" as defined by many authors (Brammer \& Millington 2004; Sharfman \& Fernando, 2008; Godfrey et al., 2009). This further reflects on the value created and is consistent with CSR's risk mitigation vision, which is fundamental to the creation of corporate reputation (Fombrun, 2005).

Maintaining a company's reputation inevitably requires constant and adequate commitment. In fact, any type of error, misdeed or breach of the law could result in reputation damage which, amplified by media representation, could have devastating consequences on a business. Moreover, in recent years, besides the well-known devasting effects of loss of reputation for wilful deeds (such as for example producing 
damaged products, fraudulent trading practices, corruption or breach of rights) a new phenomenon has emerged which involves intentional distortion of information by illicit use of multimedia: spreading fake news. This trend renders the corporate image and therefore its growth potential extremely vulnerable.

Without doubt, the use of social networks, tweets or videos as part of business and marketing strategies increases the exposure to fake news. The reputation damage risk is notably increased as a result of the double effect: on the one hand the speed at which news spreads and the number of persons that it can reach and on the other hand spreading false news weakens the reputation of a company or slows down its development.

This explains why all over the world, especially in the last five years, the evaluation and monitoring of reputation risk has become more important for companies and large groups. According to the Aon Global Risk Survey, comparing the first 15 risks in the 2017 and 2019 surveys, the fear of reputational risk is confirmed in the top positions as follows (Table 1).

Table 1: Top15 Risks for AON's 2019 Global Risk Management

\begin{tabular}{|l|r|r|}
\hline \multicolumn{1}{|c|}{ Current Top 15 Risks } & 2019 Survey & 2017 Survey \\
\hline $\begin{array}{l}\text { Economic } \\
\text { recovery }\end{array}$ & 1 & 2 \\
\hline Damage to reputation/brand & $\mathbf{2}$ & $\boldsymbol{1}$ \\
\hline $\begin{array}{l}\text { Accelerated rates of change in } \\
\text { market factors }\end{array}$ & 3 & 38 \\
\hline Business interruption & 4 & 8 \\
\hline Increasing competition & 5 & 3 \\
\hline Cyber attacks/data breach & 6 & 5 \\
\hline Commodity price risk & 7 & 11 \\
\hline Cash flow/liquidity risk & 8 & 12 \\
\hline $\begin{array}{l}\text { Failure to innovative/meet } \\
\text { customer needs }\end{array}$ & 9 & 6 \\
\hline Regulatory/legislative changes & 10 & 4 \\
\hline $\begin{array}{l}\text { Failure to attract or retain top } \\
\text { talent }\end{array}$ & 11 & 19 \\
\hline $\begin{array}{l}\text { Distribution or supply chain } \\
\text { failure }\end{array}$ & 12 & 21 \\
\hline Capital availability/credit risk & 13 & 20 \\
\hline Disruptive technologies & 14 & 9 \\
\hline Political risk/uncertainties & 15 & \\
\hline
\end{tabular}

Source: based on Global Risk Management Survey 2019 - Executive Summary, AON, p. 3.

Protecting reputation is therefore at the top of the list of dangers of perceived risk constituting an important and sensitive aspect for companies in managing their activities.

The reputation risk indicates in fact the present or future risk of a downward trend in results or services arising from the negative perspective of the corporate image by the various reference stakeholders (Bromley 2001; Wartick 2002; Melewar \& Jenkins 2002). Its vulnerability is also linked to the fact that this is a second level risk, that is derived from other events (risks) relative to each category of risk such as production, strategy, financial, legal and operating risk. 
The uncertainty of the prevention and containment of the reputation risk necessitates adoption of governance structures and control measures which are highly affected by global responsibility and achievement of objectives in line with the legal, economic social and environment forecasts.

The control system of the corporate structure must be in line with the strategic risk management vision, defined by taking into consideration the corporate network and external and internal expectations (Brondoni 2011).

This means a wider purview of control for the stakeholders responsible for the different types of control; financial, management and internal/external relations. In other words, reputation risk management is enhanced by the adoption of a responsible social strategy in order to reinforce the company's image and to limit reputation damage in the event of a crisis or temporary loss thereof.

A successful relationship between CSR, corporate performance and reputation risk, requires a profound rethink of managerial strategies, though a precise perception of this insurance is currently underdeveloped in the literature. Several studies based on consumer survey data and the so-called "halo effect of CSR", show that CSR has a good effect on the credibility and reputation of the brand, and that the credibility of the brand is involved in the mediation of the relationship between CSR and reputation (Hur, Kim, \& Woo, 2014). In addition, it is stated that the development of CSR strategies and actions reduces the attribution of blame by consumers to a company in the event of a crisis (Klein and Dawar, 2004)

A managerial approach characterised by a multi-level relationship with all stakeholders ensures long-term fidelity based on a solid reputation capable of limiting the various corporate risks, more specifically those linked to the environment and the company's sustainability. This approach is consistent with the stakeholder orientation and with a risk mitigation vision or CSR concept similar to "insurance".

$\square$ We judge the value of our results also by the way we have achieved them. Indeed, there can be no long-term growth without responsibility and respect. For several years, the Company has embarked on a path of integration sustainability issues into the business model and decisions (Remo Ruffini, Chairman and CEO Moncler).

Risk management is therefore the company's ability to positively maintain positive relations which its stakeholders, the quality of information and transparency in its communications. In this regard, models which adopt a sustainable development approach, and have in place adequate control measures, limit risks and increase the ability to limit negative effects. On the other hand, the Company that favours a maximisation of profits approach or that of a category of its stakeholders will suffer more damages from occurrence of an event involving reputation risk (Bebbington et al., 2008).

Reputation risk management should monitor the governance policy adopted and the overall responsibility of the company and the various points of view of the stakeholders in terms of profitability, competitive advantage and sustainability.

Under its Mid-Term Corporate Strategy announced on May 22, 2018, Sony aims to sustainably generate social value and maintain a 
high level of profit under the key themes of "kando"- to move people emotionally-and "getting closer to people" (Kenichiro Yoshida, President and Chief Executive Officer, Representative Corporate Executive Officer, Sony Corporation).

\section{Managing Reputation Risk and Theoretical Framework}

The scope of this paper is to define the reputation risk management process in a company with global corporate responsibility.

First of all, the analysis must consider the characteristics of the company's governance structure. In this respect, it is necessary to evaluate each company in relation to the corporate complexity including strategic and organisational aspects. It is necessary to evaluate each case taking into consideration internal and external characteristics and the context that determine corporate organisation.

On the basis of the corporate structure, it is possible to map the relevant stakeholders and the extent of responsibility involved.

\footnotetext{
$\square$ The social and economic context in continuous evolution and the increasing awareness of consumers require every company to know how to cope with the new dynamic scenarios. For this reason, a structured approach to stakeholder engagement is fundamental, also in terms of reputational risk management.

For the Intesa Sanpaolo Group, the institutionalised forms of stakeholder engagement are opportunities for listening and dialogue that are essential for understanding the level of satisfaction of its stakeholders in relation to the work carried out by the Bank. "The dialogue with stakeholders" (Intesa Sanpaolo Group).
}

At the same time, risks are identified connected to the areas of responsibility (real, potential or latent). At this point, activities undertaken to limit the risk and the organs responsible for proper management are identified.

In particular, reputation becomes the intangible asset capable of creating or preserving company value (Roberts \& Dowling, 2002) and protecting it from the damage of potential risks. At the same time, it is a potential risk whose lack of management can provoke losses. Stakeholder involvement (through CSR activities) can create the conditions to contain exposure to reputational risk and thus amplify the positive effects of a good reputation.

As Stakeholder engagement becomes the pivot for maintaining a positive reputation, companies will seek to protect and/or enhance their reputation by engaging in CSR-related activities. Consequently, the actions or activities companies developed to manage their own reputation, or to reduce reputation risks, must find adequate exposure in the company's communication. In this regard, CSR reports should include the measurement, disclosure and assurance of business information on CSR-related activities. For these reasons this study analyses reputational risk as a driving force behind the insurance aspect of CSR and the reconciliation of all dimensions of corporate responsibility. 
In this context, it is essential to introduce a reputation risk management model bearing in mind that this is a second level risk or deriving from the manifestation of other risks connected to aspects which cannot be directly influenced by governance decisions (Table 2).

Table 2: Relationship between Responsibility/Risks Dimension and Actions/Tools to Limit the Reputation Risk

\begin{tabular}{|l|l|l|l|}
\multicolumn{3}{|c|}{$\begin{array}{l}\text { Strategic configuration } \\
\text { (multiplicity ASA and result) }\end{array}$} \\
Organizational structure \\
Mission and vision \\
(governance, levels of responsibility and system of communications and controls)
\end{tabular}

\begin{tabular}{|l|l|l|l|l|}
\hline & $\begin{array}{l}\text { Control actions, } \\
\text { Sanction system, } \\
\text { System of } \\
\text { updated } \\
\text { information, } \\
\text { Automation of } \\
\text { information } \\
\text { flows }\end{array}$ & $\begin{array}{l}\text { Business planning and } \\
\text { budgeting, Control, } \\
\text { Economic analysis of } \\
\text { the variances, } \\
\text { Corrective control, } \\
\text { Upgraded information } \\
\text { systems, Automation of } \\
\text { information flows }\end{array}$ & $\begin{array}{l}\text { Quality certifications, } \\
\text { Socially responsible } \\
\text { actions, Update, Social } \\
\text { participation and } \\
\text { communication, } \\
\text { Evaluation of social } \\
\text { commitment }\end{array}$ & $\begin{array}{l}\text { Quality certifications, } \\
\text { Environmental damage } \\
\text { containment actions, } \\
\text { Actions for recovery of } \\
\text { energy, Investments in } \\
\text { alternative source, }\end{array}$ \\
& & & $\begin{array}{l}\text { Interventions of proper } \\
\text { aste disposal, } \\
\text { Recycling program, } \\
\text { Update, Involvement } \\
\text { and communication }\end{array}$ \\
& & & \\
\end{tabular}




\begin{tabular}{|c|c|c|c|c|}
\hline 8 & $\begin{array}{l}\text { Code of conduct, } \\
\text { Code of ethics, } \\
\text { Internal } \\
\text { guidelines, } \\
\text { Regulations and } \\
\text { protocols }\end{array}$ & $\begin{array}{l}\text { Business plans, } \\
\text { Operating budgets and } \\
\text { financial budgets, } \\
\text { Financial statements, } \\
\text { Reports, Guidelines, } \\
\text { Internal regulations, } \\
\text { Cost analysis, Key } \\
\text { indicator performance }\end{array}$ & $\begin{array}{l}\text { Social reporting, } \\
\text { Guidelines, Reports, } \\
\text { Code of conduct, } \\
\text { Human resource } \\
\text { policies, Sustainability } \\
\text { report, Policies on the } \\
\text { health and safety of } \\
\text { workers, Integrated } \\
\text { report, Certification, } \\
\text { Ethical code, Internal } \\
\text { regulations }\end{array}$ & $\begin{array}{l}\text { Environmental } \\
\text { reporting, Guidelines, } \\
\text { Reports, Code of } \\
\text { conduct, Environmental } \\
\text { Policy, Sustainability } \\
\text { policies, Certifications, } \\
\text { Code of ethics, Internal } \\
\text { regulations }\end{array}$ \\
\hline
\end{tabular}

The reputation risk is limited or at least its effects are mitigated by transparency of information and corporate conduct based on responsibility.

From an operational perspective, these elements are present in the adoption of corporate communication instruments aimed at expressing a strong corporate culture even from the point of view of the stakeholders inspired by principles of correctness, transparency and truth. The integration of actions of responsibility and communication instruments creates a stable and credible corporate environment.

Therefore, an integrated reputation risk management system is recommended. A unified and systematic approach is required, which is based on significant elements such as compliance with peremptory and non-obligatory rules and regulations, a governance structure, control systems, integration of risk management processes and Corporate social responsibility (CSR) which could be put forward as the management solution for reputation risk.

$\square$ "The basis for our entire business is that we are ethical, truthful and dependable. It takes time to build a reputation. We are not promoters. We are business people with a solid, permanent, constructive ethical program that will be in style years from now even more than it is today."

McDonald's success is built on a foundation of personal and professional integrity. Hundreds of millions of people around the world trust McDonald's. We earn that trust everyday by serving safe food, respecting our customers and employees and delivering outstanding Quality, Service, Cleanliness and Value (QSC\&V). We build on this trust by being ethical, truthful and dependable. In short, what Ray Kroc, founder of McDonald's Corporation said more than 50 years ago was right.

More specifically, while emphasising the importance of the above statements which are the reputation driving forces, naturally compliance with the laws in force and adopting adequate communication and control systems is essential to strengthen the company's reputation and to limit potential risk relative to the damage caused and other potential risks. These considerations are based on careful observation of the overall extent of the corporate responsibility as a global governance strategy by identifying links between the CSR and reputation risk. 
For several years, Corporate Social Responsibility has been promoting ways of engagement that are focused on social and environmental responsibility and an increasing inclusion of these issues in the traditional and institutionalized engagement activities.

In this period, the process of including stakeholders in CSR issues has progressively developed: from an initial phase where listening was substantially aimed at resolving critical situations, to the definition of structured processes which are planned each year and are increasingly based on business and management activities. Preventative listening to our stakeholders (not as a result of a "reputational crisis") aids us in establishing a relationship of trust between the company and stakeholders, and, at the same time, in identifying new opportunities with a view to competitive positioning on the market. (Intesa Sanpaolo Group - 22 March 2019).

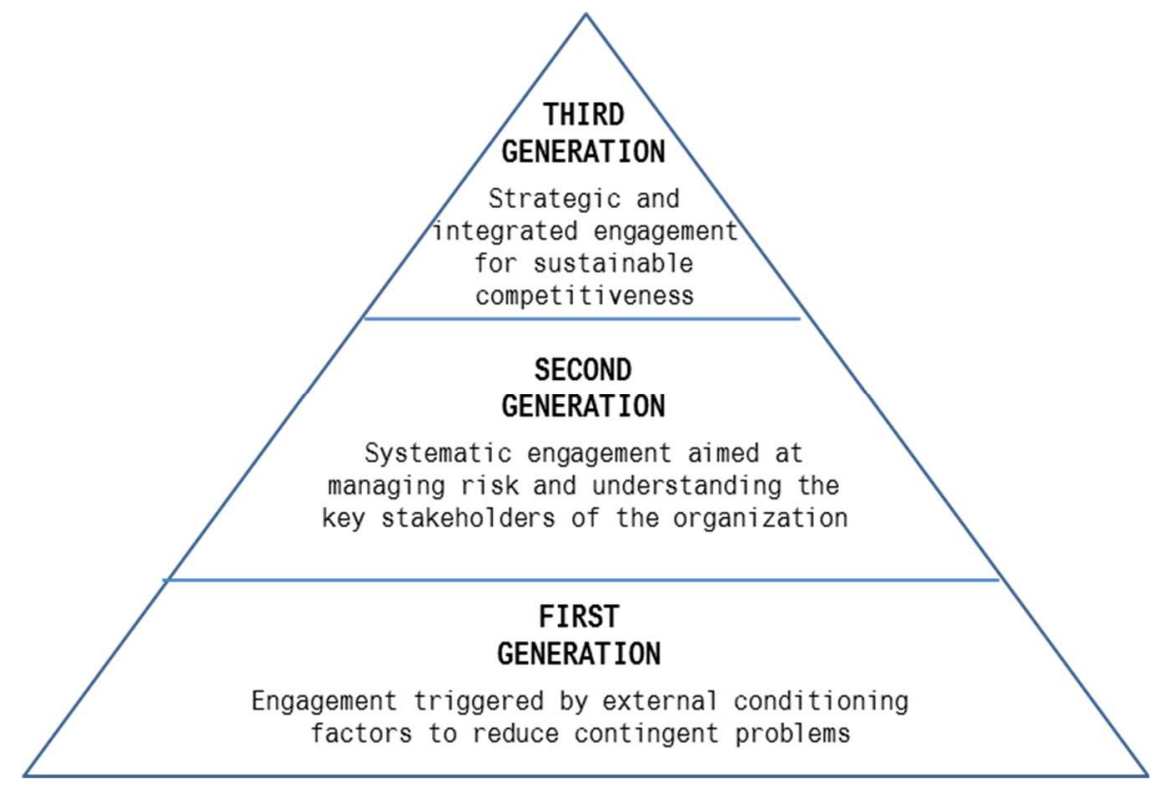

The essential point of reference for managing reputation risk is therefore identifying the profile of stakeholders having a significant involvement in the decision making process. Therefore, the relationship between quality and expectations represents the key establishing reputation driving factors.

The frameworks envisage a complex analysis of governance in order to understand whether the company's responsibility could be effectively met by means of the integrated governance of the risk with respect to the internal control system. This model places particular attention on the quality of the internal network of relations based on: corporate governance activities, forecasts, prevention and management of corporate risks, the impact of stakeholder expectations and on the internal control system. 


\section{Bibliography}

Barnett, M. L., Jermier, J. M., \& Lafferty, B. A. (2006). Corporate Reputation: The Definitional Landscape, Corporate Reputation Review, 9(1), 26-38.

http://dx.doi.org/10.1057/palgrave.crr.1550012

Bebbington, J., Larrinaga, C., \& Moneva, Jose M. (2008). Corporate Social Reporting and Reputation Risk Management, Accounting, Auditing \& Accountability Journal, 21(3), 337-361.

http://dx.doi.org/10.1108/09513570810863932

Borgonovi, E. (2007). Sustainable Economic Growth in the Global Society, Symphonya. Emerging Issues in Management (symphonya.unimib.it), (2), 50-63.

http://dx.doi.org/10.4468/2007.2.06borgonovi

Brammer, S., \& Millington, A. (2004). The Development of Corporate Charitable Contributions in the UK: A Stakeholder Analysis, Journal of Management Studies, 41(8), 1411-1434.

http://dx.doi.org/10.1111/j.1467-6486.2004.00480.x

Bromley, D. B. (2001). Relationships Between Personal and Corporate Reputation, European Journal of Marketing, 35(3/4), 316-331. http://dx.doi.org/10.1108/03090560110382048

Brondoni, S. M. (2010). Intangibles, Global Networks \& Corporate Social Responsibility, Symphonya. Emerging Issues in Management (symphonya.unimib.it), 2, 6-24.

http://dx.doi.org/10.4468/2010.2.02brondoni

Brondoni, S. M. (2011). Global Networks, Knowledge Management and World Cities, Symphonya. Emerging Issues in Management (symphonya.unimib.it), 1, 7-18.

http://dx.doi.org/10.4468/2011.1.02brondoni

Brondoni, S.M. (2014). Global Capitalism and Sustainable Growth. From Global Products to Network Globalisation, Symphonya. Emerging Issues in Management (symphonya.unimib.it), 1, 10-31.

http://dx.doi.org/10.4468/2014.1.02brondoni

Brondoni, S. M., \& Bosetti, L. (2008). Ouverture de 'Integrated CSR Management', Symphonya. Emerging Issues in Management (symphonya.unimib.it), 1, 1-17.

http://dx.doi.org/10.4468/2018.1.01ouverture

Brown, J. A., \& Forster, W. R. (2013). CSR and Stakeholder Theory: A Tale of Adam Smith, Journal of Business Ethics, 112, 301-312.

http://dx.doi.org//10.1007/s10551-012-1251-4

Cassano, R. (2013). Accountability e Stakeholder Relationship nelle Aziende Pubbliche, FrancoAngeli, Milan.

Donaldson, T., \& Preston, L. E. (1995). The Stakeholder Theory of the Corporation: Concepts, Evidence, and Implications, Academy of Management Review, 20(1), 65-91.

http://dx.doi.org/10.5465/AMR.1995.9503271992

Doorley, J., \& Garcia, H. F. (2011). Reputation Management: The Key to Successful Public Relations and corporate communication ( $3^{\text {nd }}$ ed.), New York: Routledge.

http://dx.doi.org/10.4324/9781315879987

Fombrun, C. J. (1996). Reputation: Realizing Value from the Corporate Image. Boston, Mass.: Harvard Business School Press.

Fombrun, C. J. (2005). A World of Reputation Research, Analysis and Thinking - Building Corporate Reputation through CSR Initiatives: Evolving Standards, Corporate Reputation Review, 8(1), 7-12. http://dx.doi.org/10.1057/palgrave.crr.1540235

Fombrun, C. J., Ponzi, L., \& Newburry, W. (2015). Stakeholder Tracking and Analysis: The RepTrack®System for Measuring Corporate Reputation, Corporate Reputation Review, 18(1), 3-24. http://dx.doi.org/10.1057/crr.2014.21 
Freeman, E. R., Harrison, J. S., Wicks, A. C., Parmar, B. L., \& De Colle, S. (2010). Stakeholder Theory. The State of the Art, New York: Cambridge University Press.

http://dx.doi.org/10.1017/CBO9780511815768

Freeman, E. R., \& Dmytriyev, S. (2017). Corporate Social Responsibility and Stakeholder Theory: Learning From Each Other, Symphonya. Emerging Issues in Management (symphonya.unimib.it), $1,7-15$. http://dx.doi.org/10.4468/2017.1.02freeman.dmytriyev

Gandini, G., Gennari F., \& Cassano R. (2014). Global Responsibility and Strategic Risk Management, Journal of Business Management and Applied Economics, 3(5), 1-15.

Godfrey, P. C., Merrill, C. B., \& Hansen, J. M. (2009). The Relationship between Corporate Social Responsibility and Shareholder Value: an Empirical Test of the Risk Management Hypothesis, Strategic Management Journal, 30(4), 425.

http://dx.doi.org/10.1002/smj.750

Hur, W., Kim, H., \& Woo, J. (2014). How CSR Leads to Corporate Brand Equity: Mediating Mechanisms of Corporate Brand Credibility and Reputation, Journal of Business Ethics, 125, 75-86. http://dx.doi.org/10.1007/s10551-013-1910-0

Jamali, D. (2008). A Stakeholder Approach to Corporate Social Responsibility: A Fresh Perspective into Theory and Practice, Journal of Business Ethics, 82, 213-231.

http://dx.doi.org/10.1007/s10551-007-9572-4

Klein, J., \& Dawar, N. (2004). Corporate Social Responsibility and Consumers' Attributions and Brand Evaluations in a Product-Harm Crisis, International Journal of Research in Marketing, 21, 203-217. http://dx.doi.org/10.1016/j.ijresmar.2003.12.003

Lowensberg, D. (2009). Corporate Image, Reputation and Identity. In Tench R., Yeomans L. (Eds), Exploring Public Relations ( $2^{\text {nd }}$ ed.), New York: FT Prentice Hall.

Melewar, T. C., \& Jenkins, E. (2002). Defining the Corporate Identity Construct, Corporate Reputation Review, 5(1), 76-90.

http://dx.doi.org/10.1057/palgrave.crr.1540166

Ntim, C. G., Soobaroyen, T., \& Broad, M. (2017). Governance Structures, Voluntary Disclosures and Public Accountability: The Case of Uk Higher Education Institution, Accounting, Auditing \& Accountability Journal, 30(1), 65-118.

http://dx.doi.org/10.1108/AAAJ-10-2014-1842

Perrini, F., \& Vurro, C. (2013). Stakeholder Orientation and Corporate Reputation: A Quantitative Study on US Companies, Symphonya. Emerging Issues in Management, (symphonya.unimib.it), 1, 53-65.

http://dx.doi.org/10.4468/2013.1.04perrini.vurro

Porter, M. E., \& Kramer, M. R. (2006). Strategy and Society. The Link between Competitive Advantage and Corporate Social Responsibility, Harward Business Review.

Rindova, V. P. \& Petkova, A. P. (2005). Entrepreneurial Reputation. The Blackwell Encyclopedia of Management, Blackwell Publishing, Malden: MA.

http://dx.doi.org/10.1002/9781118785317.weom030084

Roberts, P. W., \& Dowling, G. R. (2002). Corporate Reputation and Sustained Superior Financial Performance, Strategic Management Journal, 23(12), 1141.

http://dx.doi.org/10.1002/smj.274

Salvioni, D. M. (2003). Corporate Governance and Global Responsibility, Symphonya. Emerging Issues in Management (symphonya.unimib.it), 1, 44-54.

http://dx.doi.org/10.4468/2003.1.05salvioni

Salvioni, D. M. (2010). Intangible Assets and Internal Controls in Global Companies, Symphonya. Emerging Issues in Management (symphonya.unimib.it), 2, 39-51.

http://dx.doi.org/10.4468/2010.2.4salvioni 
Salvioni, D. M. (2012). Governance, Risk Management and Business Effectiveness in Global Firm, in D. Tipuric, M. Dabic (eds.), Management Governance and Entrepreunership. New Perspectives and Challenges, Access Press, Darwen.

Salvioni, D. M., \& Astori, R. (2013). Sustainable Development and Global Responsibility in Corporate Governance, Symphonya. Emerging Issues in Management (symphonya.unimib.it), 1, 2852.

http://dx.doi.org/10.4468/2013.1.03salvioni.astori

Salvioni, D. M., Astori, R., \& Cassano, R. (2015). Corporate Sustainability and Ethical codes effectiveness, Journal of Modern Accounting and Auditing, 10(9), 969-982.

http://dx.doi.org/10.2139/ssrn.2577393

Salvioni, D. M., \& Gennari, F. (2017). CSR, Sustainable Value Creation and Shareholder Relations, Symphonya. Emerging Issues in Management (symphonya.unimib.it), 1, 36-49.

http://dx.doi.org/10.4468/2017.1.04salvioni.gennari

Salvioni, D. M., Franzoni, S., Gennari, F., \& Cassano, R. (2018). Convergence in Corporate Governance Systems and Sustainability Culture, International Journal of Business Performance Management, 9(1), 7-15.

http://dx.doi.org/10.1504/IJBPM.2018.088490

Sharfman, M. P., \& Fernando, C.S. (2008). Environmental Risk Management and the Cost of Capital, Strategic Management Journal, 29(6), 569-592.

http://dx.doi.org/10.1002/smj.678

Wartick, S. L. (2002). Measuring Corporate Reputation: Definition and Data, Business \& Society, 41(4), 371-393.

http://dx.doi.org/10.1177/0007650302238774

Zucchella, A. (2007). Network Social Responsibility, Symphonya: Emerging Issues in Management (symphonya.unimib.it), 2, 64-71.

http://dx.doi.org/10.4468/2007.2.07zucchella 